ROCZNIKI FILOZOFICZNE

Tom LXVIII, numer $4-2020$

DOI: https://doi.org/10.18290/rf20684-3

DARIUSZ DĄBEK

\title{
EVOLUTIONISM-CREATIONISM: IN SEARCH FOR A PLATFORM OF DIALOGUE
}

\section{INTRODUCTION}

Inquiries concerning the relationship between evolutionism and creationism should begin by establishing the meanings of the two respective terms. Since these terms are ambiguous, differences in understanding them make discussion difficult and sometimes even impossible. Evolutionism is usually described as "a direction in philosophy and the natural sciences inspired by the biological theory of evolution of Charles Darwin and the philosophical system of Herbert Spencer" or as "a heterogeneous set of conceptual schemes, philosophical doctrines, theories and scientific hypotheses relating to evolutionary processes." ${ }^{2}$ The evolutionary way of interpreting and explaining phenomena, facts, and processes as developed in the aforementioned environment has passed and continues to pass from biology to other sciences and areas of culture. ${ }^{3}$

Evolutionism can also be understood as "a biological system of views that treats the whole animate world as a set of organic entities changing continu-

The project is funded by the Minister of Science and Higher Education under the program "Regional Initiative of Excellence" 2019-2022; project no. 028/RID/2018/19; the amount of funding: 11,742,500 PLN.

Dariusz DąBEK, PhD, Habil., Assistant Professor at the Department of the Philosophy of Inanimate Nature, Institute of Philosophy of the John Paul II Catholic University of Lublin; address for correspondence: Wydział Filozofii, Al. Racławickie 14, 20-950 Lublin, Poland; email: dariusz.dabek@kul.pl; ORCID: https://orcid.org/0000-0002-4883-5133.

1 "Ewolucjonizm [meaning 1]," Encyklopedia PWN, https://encyklopedia.pwn.pl/haslo/ewolu cjonizm; 3899380.html.

2 Józef Zon, "Ewolucjonizm," in Powszechna Encyklopedia Filozofii (Lublin: Polskie Towarzystwo Tomasza z Akwinu, 2002), 3:335.

${ }^{3}$ Józef Zon, "Ewolucja i ewolucjonizm," in Dydaktyka filozofii, vol. 7, Filozofia przyrody, ed. Dariusz Dąbek et al. (Lublin: Wydawnictwo KUL, 2013), 93. 
ously over time, i.e., evolving." " In this sense, evolutionism is sometimes use especially by biologist interchangeably with the term "theory of evolution." On the one hand, the latter term emphasizes the importance of this theory upon knowledge concerning life in the natural sciences; on the other hand, the use thereof is a way of avoiding the philosophical, methodological, and worldview controversies which arise from the application of the concept of evolution to non-biological aspects of reality. ${ }^{5}$ In this sense, the theory of evolution is not so much a scientific theory as it is a supra-theoretical conceptual scheme developed in close connection with philosophy. This schema plays a significant role in biology because it brings together almost all the disciplines of biology, and combines different theories, laws, and hypotheses into a single whole. ${ }^{6}$

The second part of the relationship under consideration, that is, creationism, is also an ambiguous term. It can be understood as a biological view, in competition with (or preceding) the theory of evolution, which considers the origin of life as a single creative act and proclaims the invariability of the form and number of species. ${ }^{7}$ This term can also be equated with the theological concept that God creates the human soul in the creation of every human being. ${ }^{8}$ Finally, creationism can be understood as a philosophical view which proclaims that the world did not arise in a purely natural way but was created by the Absolute. Two (and sometimes three) basic currents of creationism are usually distinguished: classical (sometimes divided into maximalistic and minimalistic) and evolutionary. ${ }^{9}$

\footnotetext{
${ }^{4}$ Antoni Hoffman, "Ewolucjonizm [meaning 2]," Encyklopedia PWN, https://encyklopedia. pwn.pl/haslo/ewolucjonizm;3899381.html.

${ }^{5}$ Evolution itself can be understood as: biological, biochemical, or cosmic evolution (ZoN, "Ewolucjonizm," 337). Cf. Kazimierz JodKowsKI, Metodologiczne aspekty kontrowersji ewolucjonizm - kreacjonizm (Lublin: Wydawnictwo UMCS, 1998), 27; JoDKowsKi, Spór kreacjonizmu z ewolucjonizmem. Podstawowe pojęcia i poglądy (Warsaw: Megas, 2007), 31.

${ }^{6}$ Zon, "Ewolucjonizm," 341; Zon, "Kiedy 'kreacja albo ewolucja', a kiedy 'kreacja oraz ewolucja,", in Ewolucjonizm czy kreacjonizm, ed. Imelda Chłodna et al. (Lublin: Fundacja Lubelska Szkoła Filozofii Chrześcijańskiej, 2008), 277.

${ }^{7}$ Cf. "Kreacjonizm [meaning 1]," Encyklopedia PWN, https://encyklopedia.pwn.pl/haslo/krea cjonizm;3927245.html.

${ }^{8}$ Cf. "Kreacjonizm [meaning 2]," Encyklopedia PWN, https://encyklopedia.pwn.pl/haslo/krea cjonizm;3927246.html.

${ }^{9}$ Some people make this division when taking into account the scope of creationism (JoDKOWSKI, Metodologiczne aspekty, 62), and therefore distinguish creationism either in a broader sense or in a narrower sense (supplemented by the view that creation was done by special, separate acts, such as those which led to the sudden appearance of organisms in a complex form).
} 
Classical (traditional) creationism presupposes the total dependence of all components of the world (or, in the minimalist current, only some of them, e.g., the human soul) on the Creator who not only calls all things into existence (creatio ex nihilo), but also constantly sustains their existence (creatio est continuatio). ${ }^{10}$ In evolutionary creationism, the emergence of new systems and structures is the result of both the Creator's action and evolutionary processes (the creative act is immanently linked to the processes of nature, although it does not violate the order of nature and is timeless). In both currents it is emphasized that the concept of creationism is in no way related to the temporal finiteness or infinity of the universe, with the main content of creationism thus concerning the dependence of all beings in their existence upon the Creator. ${ }^{11}$

The aim of the considerations undertaken here is to make an attempt at indicating such a level of discussion which would enable dialogu a dialogue that increases the chance of developing a coherent worldview which combines elements of scientific knowledge and religious faith. Therefore, it is not so much about joining this discussion especially the one taking place among philosophers and philosophizing scientists ${ }^{12}$ - but rather about reflecting on how to conduct such a debate. Such a reflection should be aimed at harmonizing various views of the world, ${ }^{13}$ since the pursuit of a coherent

\footnotetext{
${ }^{10}$ Cf. Andrzej Maryniarczyk, "Creatio ex nihilo," in Powszechna Encyklopedia Filozofii (Lublin: Polskie Towarzystwo Tomasza z Akwinu, 2001); MARYNIARCzyK, "Dlaczego kreacjonizm?" in Ewolucjonizm czy kreacjonizm, ed. Imelda Chłodna et al. (Lublin: Fundacja Lubelska Szkoła Filozofii Chrześcijańskiej, 2008); Zon, "Kiedy 'kreacja albo ewolucja'," 2008.

${ }^{11}$ Cf., e.g., Kazimierz KLoskowski, Filozofia ewolucji i filozofia stwarzania (Warsaw: Wydawnictwo UKSW, 1999), 1:53-66 and 2:41-52; Józef TUREK, "Wszechświat czasowo nieskończony i stworzony," Studia Warmińskie 28 (1991).

${ }^{12}$ These issues are discussed in many academic centers in Poland including Kraków (UPJPII), Lublin (KUL), Warsaw (UKSW), and Zielona Góra (UZ). The following examples can be mentioned: numerous works undertaken in the Copernicus Center for Interdisciplinary Studies (https://www.ccpress.pl/katalog/cat-Nauka_i_religia-9.html), e.g., Teologia nauki, ed. Janusz Mączka and Piotr Urbańczyk (Kraków: Copernicus Center Press, 2015); 6th International Philosophical Symposium "Evolutionism or Creationism," in the series The Future of Western Civilization (Lublin 2007), followed by Ewolucjonizm czy kreacjonizm, ed. Imelda Chłodna et al. (Lublin: Fundacja Lubelska Szkoła Filozofii Chrześcijańskiej, 2008) and numerous publications of the Zielona Góra Local Group "Science and Religion" (available on http://www.nauka-areligia.uz.zgora.pl/index.php/pl/home).

${ }^{13}$ The difficulty of such a task can be proven by the fact that the very concept of worldview, which underpins such reflections, is blurred and fuzzy in its scope. This is mainly due to the fact that one's conception of the world is created within the framework of a constantly changing, broadly understood culture which includes many different elements such as philosophical views, religious beliefs, popularized scientific concepts, and notions created by literature and art. Even
} 
vision of reality is one of the essential manifestations of human rationality. The specific objective of the research conducted here is therefore an attempt to answer the question of what conditions should be met in order for such a discussion to be an epistemically valuable dialogue aimed at better explaining and understanding reality, and not forcing one's own vision of the world as the only correct one. In order to achieve this goal, the question of the needs and possibilities of undertaking such a dialogue will be discussed first. Then, the platform of this dialogue as well as its expected results and conditions for achieving them will be presented. Finally, a summary is made in the form of conclusions and subsequent proposals.

\section{DIALOGUE: THE NEED AND POSSIBILITY THEREOF}

In the context of the multitude of ways of understanding evolutionism and creationism, it is useful and advisable to make some clarifications. In the philosophy of science three levels of scientific theories are distinguished: object-type theories, meta-objective (methodological) theories, and metamethodological theories. ${ }^{14}$ Taking into account the field of scientific research, we can speak of (i) the level of objects, facts, and phenomena; (ii) the level of the scientific structures that explain these objects, facts, and phenomena (hypotheses, laws, and theories); and (iii) the level of meta-scientific interpretation of these scientific structures. ${ }^{15}$ Thus, in relation to the issues that are the subject of the research undertaken here, we can distinguish three levels: (1) the evolutionary processes which take place in nature; (2) the theory of evolution, which is a rational reconstruction of these processes and is aimed at explaining them, inter alia, by indicating their mechanisms; and (3) evolutionism, in which, apart from the claims of natural sciences, also theses of non-scientific, e.g., philosophical positions are taken into account. ${ }^{16}$ The previously mentioned ways of understanding the term

the so-called scientific view of the world is an interpretation of (arbitrarily) selected scientific achievements rather than an objective vision of reality. Cf. Michał HeLler, "Naukowy obraz świata a zadania teologa," in Obrazy świata $w$ teologii i naukach przyrodniczych, ed. Stanisław Budzik, Michał Heller, and Stanisław Wszołek (Tarnów: Biblos, 1996): 13-19.

${ }^{14}$ Zygmunt HajduK, Filozofia nauk przyrodniczych. Uaktualniony wybór elementarnych kwestii (Lublin: Wydawnictwo KUL, 2012), 16-17.

${ }^{15} \mathrm{I}$ omit here the meta-methodological level related to evaluating and selecting the research strategy.

${ }^{16}$ Zygmunt Hajduk, Filozofia przyrody. Filozofia przyrodoznawstwa. Metakosmologia (Lu- 
'evolutionism' show that the distinction between these levels is neither obvious nor widely accepted. It seems, however, that in the process of searching for a platform of dialogue, the distinctions proposed here will significantly improve the deliberations and discussions undertaken.

The least controversial subject of scientific research is facts. However, even at this level, total neutrality is something unattainable, if only because empirical data is theory-laden. In the case of the evolutionary processes, the reconstructing of facts from the distant past is not an easy task. Something even more difficult and with a greater risk of error is to construct and test scientific theoretical structures (hypotheses, laws, and theories) that explain these aforementioned facts. It is known that two types of reasoning are involved in all explanation: reductive reasoning (i.e., selecting the inferential basis) and deductive reasoning (deriving conclusions/making inferences on that basis). Only the latter type has the value of reliability. If there were only one set of reasons from which it would be possible to deduce a conclusion according to an explained statement, we would be sure that our explanation is correct. ${ }^{17}$ The addition of various possible interpretations and philosophical generalizations to a scientific theory further increases the difficulty of finding one "correct" explanation of observed facts and processes. ${ }^{18}$

Let us try to define, by analogy, similar levels for theology. On the first of these levels, the supernatural (divine) reality should be placed as the sub-

blin: Towarzystwo Naukowe KUL, 2007), 315; the need for such a distinction can be confirmed by the statement of the author of numerous books popularizing biological knowledge: "In science, the problem of the 'theory of evolution' does not exist because almost all scientists do not treat evolution as a 'theory', but as a scientific fact; the mechanisms of evolution are the problem, not evolution itself" (Marcin Ryszkiewicz, Ziemia i życie. Rozważania o ewolucji $i$ ekologii [Warsaw: Prószyński i S-ka, 1995], 12).

${ }^{17} \mathrm{~A}$ similar argument is used by Michał Heller in relation to the difficulties of a deductive strategy of practicing cosmology, in which assumptions are made (i.e., hypotheses are put forward) about the global properties of the universe, from which, by means of deduction, local properties are derived for empirical testing. Evaluating this strategy, Heller writes that this method could provide reliable knowledge about the universe only "if it could be shown that there is one and only one set of global assumptions from which local physics results (together with results of local observations). The multitude of different cosmologies of the deductive type proves against such a possibility" (Michał Heller, "Uwagi o metodologii kosmologii," Roczniki Filozoficzne 26, no. 3 [1978]: 69).

${ }^{18}$ Even if we remain at the level of natural sciences (without the involvement of nonscientific theses), this problem is clearly visible: "Whenever Darwin's theory [of natural selection] is used, or even merely referred to, the biologist always assumes or uses a certain interpretation of this theory" (Krzysztof ŁASTOWSKI, "Lamarck i Darwin. U podstaw teorii ewolucji," in Teoria i metoda w biologii ewolucyjnej, ed. Krzysztof Łastowski [Poznań: Zysk i S-ka, 2005], 55). 
ject of theological research. ${ }^{19}$ On the second level, there are the theses formulated in theology, and on the third level, interpretations of these theses. Although the term 'theology' clearly indicates God as the object of the research undertaken in this science, a number of specific approaches to this object are mentioned: Revelation, faith, man, and Christ. In the first of these approaches, practicing theology means seeking to understand the message of salvation as revealed in the Word of God; in the second, to know the content of faith; in the third, to seek to understand man in his relationship to God; and in the fourth, to know Christ (God-Man), in whom God reveals Himself most fully and accomplishes the work of salvation. ${ }^{20}$ The obtained results of research (theological cognition) are formulated in the form of a system of statements which can be called theological knowledge. This knowledge has three specific characteristics that make it different from all other types of knowledge: a reference to Transcendence as an authority, the unquestionable character of at least some statements, and an interference of external (institutional) authority. ${ }^{21}$ Theological knowledge (of the second level) is subject to interpretation, which is made at the third level and aims to build a Christian view of the world and man.

In theology, all the elements of the first level (the object of the research) are not given in a "pure," objective, and unambiguous form, but require "discovery," interpretation, and reasoning aimed at understanding. In the set of second level elements, only some of these elements have the status of unquestionable judgments. Other components of theological knowledge are subject to development and do not have the character of immutable truths. As in other sciences, theology also makes assumptions and efforts to ensure that the entire knowledge system is internally consistent. On the third level, a meta-scientific interpretation of this knowledge is made, on the basis of which a view of the world and man is built, aiming at explaining and understanding the origin and sense of the existence thereof. This view is subject to constant development due to the temporal nature of at least some elements of theological knowledge (namely: those of the second level), which are susceptible to criticism and allowing different interpretations.

\footnotetext{
${ }^{19}$ Here I omit natural theology as a philosophical discipline and consider only proper theology, referring in its final justification to Revelation. Cf. Stanisław NAPIÓRKowski, Jak uprawiać teologię (Wrocław: Wydawnictwo Wrocławskiej Księgarni Archidiecezjalnej, 2002), 99-102.

${ }^{20}$ Ibid., 66-72.

${ }^{21}$ Ibid., 239-41.
} 
With regard to the issues constituting the main stream of the research conducted here, I propose to distinguish three levels in theology: (1) the fact of the existence of the universe and man and the revealed truth concerning God and man, (2) theological knowledge that explains this fact and interprets the dogma of creation, (3) creationism, in which, in addition to the theological knowledge which proposes its own solution to the question of the origin of existing reality, philosophical knowledge and sometimes also philosophically interpreted results of the natural sciences are taken into account. As in the case of the natural sciences, the distinction of these levels is neither unequivocal nor commonly accepted. However, it seems helpful not only in avoiding conflicts but also, and above all, in seeking a platform of dialogue. ${ }^{22}$

In the latest philosophy of science, the importance of the inter-theoretical coherence and unifying power of proposed theories is emphasized. Both of these advantages are treated as indicators of the correctness of structures constructed in science (hypotheses, laws, and theories) and are taken into account in the process of their acceptance. The point is to build an internally coherent system of knowledge allowing one to explain and understand the entirety of existing reality. ${ }^{23}$ This is largely due to the assumptio more or less openly accepte concerning the unity of nature as the object of the natural sciences research. ${ }^{24}$ The questions arise as to whether the "entirety of

${ }^{22}$ It is worth mentioning here the concept of stratification of knowledge according to its empirical testability. In his analysis of the relationship between science and religion, Piotr BYLICA ("Zarys modelu poziomów analizy w badaniach relacji nauki i religii," Filozoficzne Aspekty Genezy 9 [2012], 221-53; "Levels of Analysis in Philosophy, Religion, and Science," Zygon. Journal of Religion \& Science 50, no. 2 [2015], 304-28) proposes to distinguish the following levels: (1) general statements without empirical content ("deep" metaphysics); (2) statements that are not empirically testable and are accepted without empirical justification but are used as assumptions in the interpretation of scientific methods ("shallow" metaphysics); (3) metascientific theses that form an integral part of scientific theories and determine their content; (4) statements about nature concerning its structure and the relationship between events and properties; and (5) statements describing empirical reality.

${ }^{23}$ How far away this goal is, even at the level of physical knowledge, is evidenced by the difficulties found in implementing a research program aimed at constructing the so-called final theory or "Theory of Everything." Almost 30 years ago, Steven Weinberg wrote optimistically: "Our present theories are of only limited validity, still tentative and incomplete. But behind them now and then, we catch glimpses of a final theory, one that would beof unlimited validity and entirely satisfying in its completeness and consistency... We certainly do not have a final theory yet, and we are not likely to discover it soon. But from time to time we catch hints that it is not so very far off"' (Steven WeinBerg, Dreams of a Final Theory [New York: Vintage Books, 1994], 6). At present we still do not have a theory of quantum gravity that would combine general relativity with quantum mechanics. Cf. also John D. BARRow, New Theories of Everything (Oxford: OUP, 2007).

${ }^{24}$ Michał Heller and Janusz Mączka, Jedność nauki - jedność świata? (Tarnów: Biblos, 
existing reality" can be reduced to material reality only, whether scientific cognition can be considered as the only valuable cognition, and whether human knowledge can be limited only to verifiable empirical knowledge. Of course, it is possible to take such a position, but it must be remembered that this position consists of meta-scientific theses: ontological and epistemological theses. On a scientific level they cannot be justified. Scientists who voice such views expose themselves to accusations of reductionism and of overstepping their competences.

It is important to be aware that meta-scientific theses belong to the third level, where the evaluation of different types of knowledge and the selection of elements of the reason for inference in the process of explaining reality is made. It is at this level that, in addition to objective knowledge, ontological and epistemological theses (meta-objective assumptions) are involved. A lack of awareness of these distinctions leads to fundamentalism: (pseudo) religious or atheistic. ${ }^{25}$ A pluralism of thinking and an openness to various worldview options, while preserving the autonomy of cognitive planes (science, philosophy, and theology), allows one not only to avoid the aforementioned fundamentalism, but above all allows one to conduct an epistemically fruitful dialogue, beneficial to all parties involved. ${ }^{26}$

\section{THE PLACE OF DIALOGUE AND THE CONDITIONS OF ITS CONDUCT}

In the context of the proposed distinctions, it should be indicated at which levels, and how, such a dialogue can be conducted. The aim of such dialogue is to cognize, describe, explain, and understand the whole of existing reality, that is, all the "objects" of the first level as best we can. The realization of this cognitive goal begins at the second level and the parties involved in this dialogue are: natural sciences, philosophy, and theology. Each of these sciences has its own specific subject, its own language, and its own methods

2003); Marek SiKora, Pytanie o jedność nauki. Studium metodologiczno-filozoficzne (Bydgoszcz: Epigram, 2016).

${ }^{25}$ Józef ŻYCIŃSKI, "Epistemologiczne aspekty fundamentalistycznej interpretacji ewolucjonizmu," Zagadnienia Filozoficzne w Nauce 30 (2002): 3-4.

${ }^{26}$ Andrzej Bronk, "Teologia i nauki przyrodnicze (Uwagi na marginesie)," Roczniki Filozoficzne 39-40, no. 2 (1991-1992):16; Józef TUREK, "Metodologiczne ograniczenia procedur unaukowienia teologii," Roczniki Filozoficzne 59, no. 2 (2011): 55, https://www.jstor.org/stable/434 08931. 
with different ways of justifying its own theses (empirical factors, rational discourse, and Revelation). Attempts to blur these differences lead to a rejection of the postulate of the autonomy of these cognitive domains and to the denial of the principle of epistemological and methodological uniformity as derived from this same postulate. The principle just mentioned prohibits the free passage between scientific, philosophical, and theological theses. Failure to observe this principle leads to such intellectual abuses as, for example, the identification of the Big Bang with the absolute beginning of the universe and the recognition of it as "evidence" of the Creator's existence, or the rejection of the hypothesis of many universes on the basis of the theological argument that "the information about the salvific work of Christ could not reach other universes." 27

However, the principle of the autonomy of cognitive domains and the requirement to observe the principle of epistemological and methodological uniformity do not imply isolationism at the (second) level of natural, philosophical, and theological knowledge. The addition of, for example, philosophical theses to natural theories is neither extraordinary nor reprehensible. On the contrary, as unsuccessful attempts by representatives of logical empiricism have shown, it is not possible to eliminate metaphysical theses from science. Depending on the accepted concepts of the laws of nature, the order in the universe, or the place of man in it, certain philosophical theses will appear (explicitly or in a hidden way) in considerations concerning the natural world. The problem arises when the differences between the theses of the natural sciences and their philosophical interpretation or meta-objective assumptions are blurred. ${ }^{28}$

Although full integration of the three types of second-level knowledge (natural, philosophical, and theological) seems impossible, mutual openness to the questions posed, the research problems formulated, the hypotheses put forward, and the solutions proposed are valuable and epistemically fruitful. Dialogue undertaken at this level has an inspiring value. Although it does not lead to unification of positions, as that would require omitting specificity and the blurring of differences between different types of knowledge, this dialogue broadens the research perspectives of each of the autonomous cognitive fields, thus opening them to new issues and stimulating their development. Some natural theories pose a challenge to philosophy and theology,

\footnotetext{
${ }^{27}$ Such an argument was used by a theologian-dogmatician in a private discussion of the issues of contemporary cosmology, the hypothesis of many universes, and the relationship between the natural sciences and theology.

${ }^{28}$ Józef ŻYciŃSKI, "Epistemologiczne aspekty fundamentalistycznej interpretacji ewolucjonizmu," Zagadnienia Filozoficzne w Nauce 30 (2002): 5-6.
} 
e.g., the discovery of increasingly fundamental levels of the structure of the world requires a change in ontology. So far, this has been built upon macroscopic experience. New theories will have to take into account the need to generalize such concepts as dynamics (change), causality, time, and space, and this will cause the need to rework, among other things, the problem of God as the first cause, the temporal beginning of the universe, the problem of determinism and chance, or the individuality of being, and, in this context also, of man. ${ }^{29}$ In turn, naturalistic explanations of cosmic coincidences (the hypothesis of many universes) should not be treated by theologians or theistic philosophers as proposals that deny the existence of God as Creator, but as an inspiration to undertake research with such hypotheses in mind. ${ }^{30}$ Similarly, the theory of evolution should be treated as a challenge to the search for new concepts in philosophy and theology rather than as a threat to faith in God or as a depreciation of human dignity. ${ }^{31}$

This mutual respect and openness to other types of knowledge cannot conceal the fact that none of them have the status of being certain and ultimate knowledge. The generalization and extrapolation of procedures used in the natural sciences and the lack of conclusive evidence and final justification make knowledge of the natural world inconclusive and, by its very nature, correctable. The inaccuracy of measurements, the possibility of error, and the underdetermination of theory by empirical data susceptible to interpretation determine the approximate nature of this knowledge, treated as an inherent feature of scientific research. This is evidenced by historical cases of changes in both issues and proposed solutions, as well as in changes in facts previously considered unquestionable. Thus, natural knowledge is tem-

\footnotetext{
${ }^{29}$ Michał Heller, "The Ontology of the Planck Scale," in Between Philosophy and Science, ed. Bartosz Brożek, Michał Heller, and Łukasz Kurek (Kraków: Copernicus Center Press, 2013), $128-29$.

${ }^{30}$ For strategies of undertaking such research see Jacek WoJTYSIAK, "O możliwych strategiach teologa wobec nauki," Roczniki Filozoficzne 59, no. 2 (2011): 325-44, https://www.jstor.org/ stable/i40135089.

${ }^{31}$ Some also point out the inspiring influence of Christianity on the development of modern science. For example, Józef Życiński believes that "this was not a result of a chance, but a consequence of intellectual and cultural conditions which were greatly influenced by the concept of God's immanence in nature and the concept of creation as a free act of God" (Józef ŻYCIŃSKI, Inspiracje chrześcijańskie w powstawaniu nauki nowożytnej [Lublin: Wydawnictwo KUL, 2000], 8). Cf. Wojciech Котоwicz, “Józefa Życińskiego meta-przedmiotowe ujęcie relacji między nauką a religią," Roczniki Filozoficzne 60, no. 4 (2012): 249-60; Piotr GuTOwski, “Józefa Życińskiego koncepcja relacji między religią a nauką," Przegląd Filozoficzny - Nowa Seria 85, no. 1 (2013): 15-30. See also Zbigniew LiAnA, "Inspiracje chrześcijańskie w rozwoju myśli naukowej," in Nauki przyrodnicze a teologia: konflikt i wspótistnienie, ed. Michał Heller et al. (Tarnów: Biblos, 2001), 75-93.
} 
poral, probable, susceptible to change, and constantly improved. ${ }^{32}$ This however does not undermine the value of natural knowledge or respect for the ways in which it is acquired, much less does it justify cognitive skepticism.

Other types of knowledge are also subject to criticism and do not have the character of certain and definitive knowledge. Although some theses are considered unquestionable in theology, only some truths of faith have such a status. The theologian, as opposed to the scientist and philosopher, who have no external authority imposed, must take into account in his research the position of the Church's magisterium. ${ }^{33}$ This office is the guardian and interpreter of the deposit of revealed truths. This position cannot create, supplement, or change these truths, but can interpret them and communicate them to the faithful. The statements of this office have a varied theological significance. Some of them are considered irrefutable, e.g., the decisions of the councils or the solemn teaching of the Pope (the so-called ex cathedra teaching) on matters of faith and morality, which oblige all the faithful of the Church to obey. However, the criteria for determining the degree of infallibility in these statements has not yet been fully established. ${ }^{34}$ The history of theology and contemporary research clearly show the continuous development of this field of knowledge and testify to the temporal nature of theological knowledge.

Both scientific and theological knowledge cannot be separated from philosophical knowledge, which is present in them in the form of ontological, epistemological, and methodological assumptions. These assumptions are of a very different nature and insightful philosophical analysis is needed to clearly indicate the which, at times, means unearthing them, as they are sometimes hidden or accepted unconsciously. ${ }^{35}$ A lack of such reflection leads to the overlooking of the aforementioned principle of epistemological and methodological uniformity, which may result in various types of fundamentalisms. Such fundamentalisms appear on the third level, where interpretation of the subject knowledge (the assertions of the second level) is carried ou sometimes in a fairly loose way. Illustrative examples of such abuses can be found in the argumentation in favor of the thesis of the creation of the world from nothing that refers to natural knowledge of the Big Bang, in the

\footnotetext{
${ }^{32}$ It should be emphasized that natural sciences are not the only source of valuable knowledge, since the integral components of such knowledge are humanistic, social, and involve cultural disciplines, as well as the ethical aspects of science itself. Cf. Zygmunt HaJduK, Nauka a wartości: Aksjologia. Aksjologia epistemiczna (Lublin: Towarzystwo Naukowe KUL, 2011), 368.

${ }^{33}$ NAPIÓRKOWSKI, Jak uprawiać teologię, 191.

${ }^{34}$ Ibid., 196.

${ }^{35}$ ŻYCIŃSKI, Epistemologiczne aspekty, 8-9.
} 
derivation of the conclusion of the non-existence of God from the theory of biological evolution, or in the rejection of the hypothesis of many universes on the basis of current theological concepts. ${ }^{36}$

The proposed divisions may seem artificial and difficult to carry out. However, this is not an attempt at dichotomous separation of levels, it would be unrealistic to hope for such an operation to be successful. The transitions between these levels are continuous and not discrete (as in the case of electrons, which cannot occupy intermediate positions between energy levels). The elements of the first level are theory-laden and interpreted in the light of constantly changing knowledge (of the second level), which cannot be separated from arbitrarily chosen philosophy. The presence of this chosen philosophy in science means that scientific theories do not have to be worldview neutral, and a view of reality built on the third leve a view referring to different kinds of knowledg can be very diverse. ${ }^{37}$

In this context, the thesis proposing the irresolvable nature of the evolutionism-creationism dispute ${ }^{38}$ seems to be perfectly correct. The dispute takes place primarily at the third level, not the second. Therefore, it is no wonder that even among biologists there are also, although few, supporters of creationism (in its many variations). Not all naturalists who accept the biological theory of evolution (second level) must adopt the same philosophy of evolution (third level) and derive from this philosophy the same metaphysical conclusions used in constructing their own view of reality. ${ }^{39}$

The thesis that argues that the dispute between evolutionism and creationism is taking place at the third level may be confirmed by analysis of the creationists'

\footnotetext{
${ }^{36}$ Cf. Dariusz DĄBEK, "Metodologiczne granice naturalistycznej interpretacji biologicznej teorii ewolucji," in Teoria ewolucji a wiara chrześcijan, ed. Katarzyna Parzych-Blakiewicz and Edward Wiszowaty (Olsztyn: Wydawnictwo UWM, 2010), 85-97; DĄBEK, “Zastrzeżenia wobec kreacjonistycznej interpretacji Wielkiego Wybuchu,” Roczniki Filozoficzne 59, no. 2 (2011): 73-90. It is also a misconception to say that creationist theses can be justified by remaining on the second level. This results in attempts to construct the so-called "scientific" creationism.

${ }^{37}$ Piotr Bylica, "Komplementarność nauki i religii," Filozofia Nauki 14, no. 1 (2006): 67.

${ }^{38}$ Kazimierz JoDKOwSKI, "Zasadnicza nierozstrzygalność sporu ewolucjonizm-kreacjonizm," Przeglad Filozoficzny - Nowa Seria 83, no. 3 (2012), doi:10.2478/v10271-012-0075-5.

${ }^{39}$ This is emphasized by Życiński, who refers to Stephen J. Gould's views: "Contrary to Dennett or Dawkins, Gould does not claim that Darwinism requires by its very nature the rejection of religious faith. In his opinion, it is only the philosophical message of Darwinism that leads to a vision of a world far removed from religion. In his opinion, the essence of this message is expressed by the thesis that evolution has no direction or purpose and that the physicobiological structure of the world is the only objective reality beyond which there is no supernatural world described by theology" (ŻYCIŃSKI, "Epistemologiczne aspekty," 9-10).
} 
appeal to scientists to sign a petition demanding research on the facts claimed to support Darwin's theory of evolution. ${ }^{40}$ Kazimierz Jodkowski writes: ${ }^{41}$

There is no question of creationism in this call. This appeal has a weaker meaning. It is not a criticism of all evolutionism, but of one form of it. It is only about doubts concerning the effectiveness of the mechanism of evolution invented by Darwin, and not the fact of evolution itself. Among the signed, therefore, there are also evolutionists, but non-Darwinists.

In this analysis you can clearly see the three levels that were distinguished earlier: (1) the fact of evolution, (2) Darwin's proposed mechanism, which was meant to explain the process of evolution, and (3) the evaluation of the effectiveness of this mechanism. At the third level decisions are made on the evaluation of the structures constructed in science (especially theories), i.e., the elements of the second level. These decisions are value judgments based on certain qualifications, especially cognitive ones, called advantages, qualities, requirements, or epistemic values. Such decisions are also influenced by non-cognitive factors such as historical, psychological, social, and cultural conditions. ${ }^{42}$

In actual research practice, scientists make comparisons, choices, evaluate, decide on the direction of research, and accept or reject the results obtained. Such decisions always involve, more or less consciously, a certain theory of values, mainly cognitive, but the non-epistemic context in which these values function is also taken into account. ${ }^{43}$ Depending on philosophical positions and currents, these values are assigned a different importance. This applies to both empirical qualities (e.g., high testability, rich empirical content, diverse supporting evidence, positive experimental test results) and theoretical values (e.g., internal consistency, coherence with recognized theories, simplicity, content capacity, explanatory and projective power). ${ }^{44}$

\footnotetext{
${ }^{40}$ The content of this appeal is quoted by JODKOwSKI in "Zasadnicza nierozstrzygalność," 203-4: "We are skeptical of claims for the ability of random mutation and natural selection to account for the complexity of life. Careful examination of the evidence for the Darwinian theory should be encouraged." Cf. http://www.dissentfromdarwin.org/.

${ }^{41}$ JoDKOwsKi, "Zasadnicza nierozstrzygalność," 204.

${ }^{42}$ HajduK, Nauka a wartości, 5-7.

${ }^{43}$ Agnieszka LeKKa-Kowalik, Odkrywanie aksjologicznego wymiaru nauki (Lublin: Wydawnictwo KUL, 2008), 106-25; HAJDUK, Nauka a wartości, 303-20.

${ }^{44}$ The role of these criteria, especially non-empirical criteria, in procedures of comparing, assessing, selecting, and accepting theoretical scientific structures is considered to be one of the most important issues of the contemporary philosophy of science. Cf. Nicolas MAXweLL, "Nonempirical Requirements Scientific Theories Must Satisfy: Simplicity, Unity, Explanation,
} 
The task of philosophy is to take care of the rationality of conducted discussion, to be open to a variety of arguments, to remove mutual prejudices, and to help build a coherent vision of the world and man. In the implementation of this multidimensional task, a special role is played by broadly understood methodology and the multifaceted philosophy of nature. Concord$\mathrm{ism}^{45}$ on the second level is an unrealistic postulate. It is an incorrect strategy to try to reconcile science and religion by changing (narrowing) the meaning of religious concepts in order to fit them to with the results of the natural sciences. ${ }^{46}$ Instead of promoting isolationism as a way to avoid "artificial conflicts," $"$ it is necessary to distinguish knowledge from its philosophical interpretations and world-view ideas, and to transfer the dialogue between evolutionism and creationism to the third level. At this level, the fundamental problem is IBE (Inference to the Best Explanation), i.e., the justification why one prefers this and no other explanation aimed at understanding oneself and the world. Since this type of justifying hypotheses (also called abduction, retroduction, or abductive reasoning) cannot be regarded as an infallible way of inferring, ${ }^{48}$ one should reject all certism and fundamentalism, and accept pluralism, in order to be open to the arguments of others and conduct dialogue in this spirit.

\section{CONCLUSIONS AND PROPOSALS}

A significant improvement in the search for a platform of dialogue between evolutionism and creationism is the distinction between the three methodological levels: (1) the object of research, (2) the knowledge of reality being studied, and (3) the interpretation of this knowledge. In relation to evolutionary views these methodological levels are: facts, phenomena, and processes (evolution); the natural knowledge which explains these facts (the theory of evolution); and interpretation of this knowledge (evolutionism). In

Beauty," in Karl Popper, Science and Enlightenment, ed. Nicholas Maxwell (London: UCL Press, 2017), 125-42.

${ }^{45}$ Dominique Lambert, Ryzykowne spotkanie teologii z nauka, trans. Paloma Korycińska (Kraków: Copernicus Center Press, 2018), 94-113.

${ }^{46}$ Piotr BYLICA, "Zarys modelu poziomów analizy w badaniach relacji nauki i religii," Filozoficzne Aspekty Genezy 9 (2012): 222.

${ }^{47}$ ŻYCIŃSKI, Epistemologiczne aspekty, 17.

${ }^{48}$ Mariusz Urbański, Rozumowania abdukcyjne. Modele i procedury (Poznań: Wydawnictwo Naukowe UAM, 2009). 
relation to creationist views these levels are: facts concerning the existence of the world and man as well as revealed truths; the theological knowledge which explains these facts and interpretation of the dogma of creation; and interpretation of theological knowledge (creationism).

This division is not discrete in the sense of being isolated, separate areas. Access to the first level is difficult since facts (including revealed truth) are not given in a "pure" form. They therefore require interpretation. At the second level, explanatory efforts are made which, because of their abductive (retroductive) nature, do not constitute reliable reasoning. Selecting the inferential basis is subject to the risk of error. In addition, at both the second and third levels, philosophical theses (ontological, epistemological, and methodological) are involved. All of this makes it very difficult to separate the planes precisely, but attempts to completely blur the boundaries thereof can lead to (pseudo-)religious or atheistic fundamentalism.

Distinguishing these three levels helps make participants of the debate aware of the fact that the proper level of discussion between supporters of evolutionism and creationism is the third level. Although dialogue ${ }^{49}$ and even interaction ${ }^{50}$ are possible and needed already at the second level, the independence of natural and theological knowledge based on mutual autonomy is recommended here.

The resulting prohibition of confusing cognitive orders, e.g., in inferring, defining, justifying, and explaining, avoids conflicts and cognitive chaos and permits the thesis that there is no contradiction between science and faith to be accepted (conflicts are then treated as the result of exceeding the competences of one of the parties. ${ }^{51}$ This does not imply isolationism, however, but rather respect for distinctiveness and mutual openness, especially in terms of inspiration in undertaking and developing one's own research. While respecting the principle of the autonomy of scientific and religious knowledge, and at

\footnotetext{
${ }^{49}$ Ian G. BARBour, When Science Meets Religion. Enemies, Strangers, or Partners? (New York: Harper Collins, 2000), 23-27.

${ }^{50}$ Michał Heller, Nauka i Teologia-niekoniecznie tylko na jednej planecie (Kraków: Copernicus Center Press, 2019), chap. 2.3.2.

${ }^{51}$ Cf. Józef Turek, "Doświadczenie dialogu ze światem nauki," in Od konfrontacji do dialogu. Doświadczenia Kościoła XX wieku. Materiały Tygodnia Eklezjologicznego 2000, ed. Andrzej Czaja, Violetta Kmiecik, and Krzysztof Kowalik (Lublin: Gaudium, 2003), 367-73. Georges Lemaitre advocated this approach to the relationship between science and faith. Cf. Józef Turek, "Poglądy metakosmologiczne G. Lemaître'a," Roczniki Filozoficzne 32, no. 3 (1984): 3147, https://www.jstor.org/stable/43409613; George V. Coyne, "Georges Lemaître: Science and Religion," in Georges Lemaître: Life, Science and Legacy, ed. Rodney D. Holder and Simon Mitton (Berlin: Springer, 2012).
} 
the same time being open to the problems formulated and solutions proposed by both sides, dialogue is possible and cognitively valuable (inspiring) even at the second level. This approach was recommended by John Paul II:

The unity that we seek ... is not identity. The Church does not propose that science should become religion or religion science. On the contrary, unity always presupposes the diversity and the integrity of its elements.... To be more specific, both religion and science must preserve their autonomy and their distinctiveness. Religion is not founded on science nor is science an extension of religion. Each should possess its own principles, its pattern of procedures, its diversities of interpretation and its own conclusions. Christianity possesses the source of its justification within itself and does not expect science to constitute its primary apologetic.... The unprecedented opportunity we have today is for a common interactive relationship in which each discipline retains its integrity and yet is radically open to the discoveries and insights of the other. ${ }^{52}$

The right place for dialogue is the third level, where knowledge is interpreted and a view of the world is built. At this level, there is a discussion on the choice and role of assumptions regarding ontology (monism/dualism), epistemology (the partiality and aspectivity of each cognition), worldview, and religion. Mutual respect, without trying to reduce and subjugate disparate beliefs, is the foundation of a dialogue aimed at explaining and understanding the whole of reality. This is an endless process of building a coherent view of the world and man, or at least of showing that fragments from science and religion do not have to be mutually exclusive. The task of philosophy is to work out and control the observance of such principles of discussion in order to not only prevent the growth of conflict, but also to contribute to a deepening of the dialogue between these important cognitive planes. ${ }^{53}$ At this level, dialogue can and should lead to the integration of all the elements that create the most coherent worldview. The manner in which this goal is achieved, the corresponding methodological and epistemological difficulties, as well as the issue of evaluating the results of such a dialogue should be the subject of further research.

\footnotetext{
52 John Paul II, Letter to Father George V. Coyne, Director of the Vatican Observatory (June 1, 1988), accessed August 22, 2020, http://www.vatican.va/content/john-paul-ii/en/letters/1988/ documents/hf_jp-ii_let_19880601_padre-coyne.html.

${ }^{53}$ Cf. TuREK, "Doświadczenie dialogu," 373.
} 


\section{BIBLIOGRAPHY}

Barbour, Ian G. When Science Meets Religion. Enemies, Strangers, or Partners? New York: Harper Collins, 2000.

BARrow, John D. New Theories of Everything. Oxford: OUP, 2007.

Bronk, Andrzej. "Teologia i nauki przyrodnicze (Uwagi na marginesie)." Roczniki Filozoficzne 39-40, no. 2 (1991-1992): 5-38. https://www.jstor.org/stable/43407897.

BylicA, Piotr. “Komplementarność nauki i religii.” Filozofia Nauki 14, no. 1 (2006): 59-68.

ByLicA, Piotr. "Zarys modelu poziomów analizy w badaniach relacji nauki i religii." Filozoficzne Aspekty Genezy 9 (2012): 221-53.

BylicA, Piotr. "Levels of Analysis in Philosophy, Religion, and Science." Zygon. Journal of Religion \& Science 50, no. 2 (2015): 304-28. doi:10.1111/zygo.12179.

Coyne, George V. "Georges Lemaître: Science and Religion.” In Georges Lemaître: Life, Science and Legacy, edited by Rodney D. Holder and Simon Mitton, 69-74. Berlin: Springer, 2012.

DĄBEK, Dariusz. "Metodologiczne granice naturalistycznej interpretacji biologicznej teorii ewolucji." In Teoria ewolucji a wiara chrześcijan, edited by Katarzyna Parzych-Blakiewicz and Edward Wiszowaty, 85-97. Olsztyn: Wydawnictwo UWM, 2010.

DĄBEK, Dariusz. "Zastrzeżenia wobec kreacjonistycznej interpretacji Wielkiego Wybuchu." Roczniki Filozoficzne 59, nr 2 (2011): 73-90. https://www.jstor.org/stable/43408932.

Gutowski, Piotr. "Józefa Życińskiego koncepcja relacji między religią a nauką.” Przegląd Filozoficzny - Nowa Seria 85, no. 1 (2013): 15-30.

HaJduk, Zygmunt. Filozofia przyrody. Filozofia przyrodoznawstwa. Metakosmologia. Lublin: Towarzystwo Naukowe KUL, 2007.

HAJDuk, Zygmunt. Nauka a wartości: Aksjologia nauki. Aksjologia epistemiczna. Lublin: Towarzystwo Naukowe KUL, 2011.

HaJduk, Zygmunt. Filozofia nauk przyrodniczych. Uaktualniony wybór elementarnych kwestii. Lublin: Wydawnictwo KUL, 2012.

Heller, Michał. "Naukowy obraz świata a zadania teologa." In Obrazy świata w teologii i naukach przyrodniczych, edited by Stanisław Budzik, Michał Heller, and Stanisław Wszołek, 13-27. Tarnów: Biblos, 1996.

Heller, Michał. "The Ontology of the Planck Scale." In Between Philosophy and Science, edited by Bartosz Brożek, Michael Heller, and Łukasz Kurek, 119-29. Kraków: Copernicus Center Press, 2013.

Heller, Michał. Nauka i Teologia - niekoniecznie tylko na jednej planecie. Kraków: Copernicus Center Press, 2019.

Heller, Michał. “Uwagi o metodologii kosmologii.” Roczniki Filozoficzne 26, no. 3 (1978): 65-75. https://www.jstor.org/stable/43409547.

Heller, Michał, and Janusz MączKa. Jedność nauki-jedność świata? Tarnów: Biblos, 2003.

JoDKowski, Kazimierz. Metodologiczne aspekty kontrowersji ewolucjonizm - kreacjonizm. Racjonalizm, racjonalność, relatywizm 35. Lublin: Wydawnictwo UMCS, 1998.

Jodkowski, Kazimierz. Spór kreacjonizmu z ewolucjonizmem. Podstawowe pojęcia i poglady. Warszawa: Megas, 2007.

JoDKowsKi, Kazimierz. “Zasadnicza nierozstrzygalność sporu ewolucjonizm-kreacjonizm.” Przegląd Filozoficzny - Nowa Seria 83, no. 3 (2012): 201-22. doi:10.2478/v10271-012-0075-5. 
John Paul II. Letter to Father George V. Coyne, Director of the Vatican Observatory. June 1, 1988. Accessed August 22, 2020. http://www.vatican.va/content/john-paul-ii/en/letters/ 1988/documents/hf_jp-ii_let_19880601_padre-coyne.html.

KLosKowsKI, Kazimierz. Filozofia ewolucji i filozofia stwarzania. 2 vols. Warsaw: Wydawnictwo UKSW, 1999.

Kотоwicz, Wojciech. 2012. “Józefa Życińskiego meta-przedmiotowe ujęcie relacji między nauką a religią." Roczniki Filozoficzne 60, no. 4 (2012): 249-60.

LAMBERT, Dominique. Ryzykowne spotkanie teologii z nauka (original French title: Sciences et théologie: les figures d'un dialogue). Translated by Paloma Korycińska. Kraków: Copernicus Center Press, 2018.

LekKa-Kowalik, Agnieszka. Odkrywanie aksjologicznego wymiaru nauki. Lublin: Wydawnictwo KUL, 2008.

LiAnA, Zbigniew. "Inspiracje chrześcijańskie w rozwoju myśli naukowej.” In Nauki przyrodnicze a teologia: konflikt $i$ współistnienie, edited by Michał Heller, Zbigniew Liana, Janusz Mączka, and Włodzimierz Skoczny, 75-93. Tarnów: Biblos, 2001.

ŁAstowski, Krzysztof. "Lamarck i Darwin. U podstaw teorii ewolucji." In Teoria i metoda w biologii ewolucyjnej. Poznańskie Studia z Filozofii Humanistyki 7, edited by Krzysztof Łastowski, 57-88. Poznań: Zysk i S-ka, 2005.

Maryniarczyk, Andrzej. “Creatio ex nihilo.” In Powszechna Encyklopedia Filozofii, 2:306-18. Lublin: Polskie Towarzystwo Tomasza z Akwinu, 2001.

MARYNIARCZYK, Andrzej. "Dlaczego kreacjonizm?” In Ewolucjonizm czy kreacjonizm, edited by Imelda Chłodna, Piotr Jaroszyński, Magdalena Smoleń-Wawrzusiszyn, and Paweł Tarasiewicz, 41-91. Lublin: Fundacja Lubelska Szkoła Filozofii Chrześcijańskiej, 2008.

Maxwell, Nicholas. "Non-empirical Requirements Scientific Theories Must Satisfy: Simplicity, Unity, Explanation, Beauty." In Karl Popper, Science and Enlightenment, edited by Nicholas Maxwell, 125-42. London: UCL Press, 2017.

MączKa, Janusz, and Piotr UrbańczyK, eds. Teologia nauki. Kraków: Copernicus Center Press, 2015.

NAPIÓRKowSKI, Stanisław C. Jak uprawiać teologię. Wrocław: Wydawnictwo Wrocławskiej Księgarni Archidiecezjalnej, 2002.

Ryszkiewicz, Marcin. Ziemia i życie. Rozważania o ewolucji i ekologii. Warsaw: Prószyński i S-ka, 1995.

SiKora, Marek. Pytanie o jedność nauki. Studium metodologiczno-filozoficzne. Bydgoszcz: Epigram, 2016.

Turek, Józef. "Poglądy metakosmologiczne G. Lemaître’a.” Roczniki Filozoficzne 32, no. 3 (1984): 31-47. https://www.jstor.org/stable/43409613.

TuReK, Józef. 1991. “Wszechświat czasowo nieskończony i stworzony.” Studia Warmińskie 28 (1991): 217-33.

TUREK, Józef. "Doświadczenie dialogu ze światem nauki." In Od konfrontacji do dialogu. Doświadczenia Kościoła XX wieku. Materiały Tygodnia Eklezjologicznego 2000, edited by Andrzej Czaja, Violetta Kmiecik, and Krzysztof Kowalik, 367-73. Lublin: Wydawnictwo Gaudium, 2003.

TUReK, Józef. "Metodologiczne ograniczenia procedur unaukowienia teologii." Roczniki Filozoficzne 59, no. 2 (2011): 53-69. https://www.jstor.org/stable/43408931.

Urbański, Mariusz. Rozumowania abdukcyjne. Modele i procedury. Poznań: Wydawnictwo Naukowe UAM, 2009. 
WeinBerg, Steven. Dreams of a Final Theory. New York: Vintage Books 1994.

WoJTYSiAK, Jacek. "O możliwych strategiach teologa wobec nauki." Roczniki Filozoficzne 59, no. 2 (2011): 325-44. https://www.jstor.org/stable/i40135089.

Zon, Józef. "Ewolucjonizm.” In Powszechna Encyklopedia Filozofii, 3:335-51. Lublin: Polskie Towarzystwo Tomasza z Akwinu, 2002.

ZoN, Józef. "Kiedy 'kreacja albo ewolucja', a kiedy 'kreacja oraz ewolucja'.” In Ewolucjonizm czy kreacjonizm, edited by Imelda Chłodna, Piotr Jaroszyński, Magdalena Smoleń-Wawrzusiszyn, and Paweł Tarasiewicz, 275-302. Lublin: Fundacja Lubelska Szkoła Filozofii Chrześcijańskiej, 2008.

ZoN, Józef. "Ewolucja i ewolucjonizm.” In Dydaktyka filozofii, vol. 7, Filozofia przyrody, edited by Dariusz Dąbek, Justyna Herda, Stanisław Janeczek, and Anna Starościc, 87-113. Lublin: Wydawnictwo KUL, 2013.

ŻYCIŃSKI, Józef. Inspiracje chrześcijańskie w powstawaniu nauki nowożytnej. Lublin: Wydawnictwo KUL, 2000.

ŻYCIŃSKI, Józef. "Epistemologiczne aspekty fundamentalistycznej interpretacji ewolucjonizmu." Zagadnienia Filozoficzne w Nauce 30 (2002): 3-17.

\section{EVOLUTIONISM-CREATIONISM: IN SEARCH FOR A PLATFORM OF DIALOGUE \\ $\mathrm{Sum}$ m a ry}

This article seeks to indicate a platform for discussion between evolutionists and creationists, which will enable dialogue and increase the chance of developing a coherent worldview that combines elements of scientific knowledge and religious faith. In the context of various types of knowledge, three levels are indicated: (1) the subject of research, (2) knowledge of this subject, and (3) interpretation of this knowledge. Dialogue can be undertaken and conducted already at the second level, but only accompanied by both respect for mutual autonomy and a focus on inspiration rather than integration. The appropriate level of dialogue is the third level: the interpretation of knowledge and building an overarching view of the world and man. The aim of dialogue at this level is to integrate all elements of a worldview and to strive to explain and understand the whole reality.

Keywords: evolution; dialogue between evolutionism and creationism; relationship between science and religion; philosophy of science.

\section{EWOLUCJONIZM-KREACJONIZM. POSZUKIWANIE PŁASZCZYZNY DIALOGU

$$
\text { Streszczenie }
$$

W artykule przedstawiona została próba wskazania płaszczyzny dyskusji ewolucjonistów z kreacjonistami, która umożliwiałaby dialog zwiększający szansę wypracowania spójnego światopoglądu łączącego elementy wiedzy naukowej i wiary religijnej. W odniesieniu do różnych typów wiedzy zaproponowane zostało wyróżnienie trzech poziomów: 1) przedmiot badań, 2) wiedza o tym przedmiocie, 3) interpretacja tej wiedzy. Dialog może być prowadzony już na poziomie drugim, lecz z poszanowaniem wzajemnej autonomii i ukierunkowaniem raczej na inspirację, niż 
na integrację. Właściwą płaszczyzną dialogu jest poziom trzeci: interpretacja wiedzy oraz budowanie wizji świata i człowieka. Celem dialogu na tym poziomie jest integracja wszystkich elementów światopoglądu i dążenie do wyjaśnienia i zrozumienia całej rzeczywistości.

Slowa kluczowe: ewolucja; dialog ewolucjonizm-kreacjonizm; relacja nauka-religia; filozofia nauki. 